SCJR 13, no. 1 (2018): 1-12

\title{
Luther, Lutherans, and Jews: Looking to the Second Five Hundred Years ${ }^{1}$
}

\author{
PETER A. PETTIT \\ peterpettit@muhlenberg.edu \\ Muhlenberg College, Allentown, PA 18104
}

\section{Martin Luther's Anti-Jewish Record and its Legacy}

We begin with the awareness that the topic of Luther and the Jews is hardly a new one. Some of Luther's contemporaries were troubled by the invective he poured out on a people with whom he was not personally well acquainted. ${ }^{2}$ It can be argued that Luther's own writings on the Jews were not especially influential over subsequent centuries, ${ }^{3}$ yet it is clear that his attitudes and the influence of his theological paradigms helped to shape the familiar modern forms of anti-Judaism. Among Jewish communities, it was Luther's anti-Jewish recommendations that were best known, prompting Fr. Edward Flannery's famous metaphorical observation: the blood-stained pages that Christians have torn from their history books have been memorized by Jews. ${ }^{4}$ When the architects and propagandists of Nazi's proposed Final Solution needed them, Luther and his writings stood ready to be exploited, and they were. ${ }^{5}$ Sadly, they have continued to be trumpeted by neoNazis and other bigots down to our own day.

\footnotetext{
${ }^{1}$ I am grateful to the institutions and hosts whose invitations prompted these reflections and the specific research on which they are grounded. Please see the endnote for a complete list. In each venue I was warmly welcomed and enjoyed the reward and stimulation of lively discussion, leading to my own growth and the continual focusing, sharpening, and clarifying of the ideas. All remaining diffuseness, dullness, and murkiness are, of course, my own responsibility; further correction and improvement by the readers will be most welcome.

${ }^{2}$ See Hans Hillerbrand, "Introduction," in The Annotated Luther, vol. 5, Christian Life in the World, ed. Hans Hillerbrand (Minneapolis: Fortress Press, 2017), 443. See also Brooks Schramm, "Introduction," and Kirsi I. Stjerna, "Introduction," in Martin Luther, The Bible, and the Jewish People: A Reader, ed. Brooks Schramm and Kirsi I. Stjerna (Minneapolis: Fortress Press, 2012), 5, 24.

${ }^{3}$ See Johannes Wallmann, "The Reception of Luther's Writings on the Jews from the Reformation to the End of the $19^{\text {th }}$ Century," in Stepping-Stones to Further Jewish-Lutheran Relationships: Key Lutheran Statements, ed. Harold H. Ditmanson (Minneapolis: Augsburg, 1990), 120-136.

${ }^{4}$ Edward H. Flannery, The Anguish of the Jews: Twenty-Three Centuries of Antisemitism, A Stimulus Book (Mahwah, NJ: Paulist Press, 1985), 1.

${ }^{5}$ See "The Handbook of the German Christians (1933)," in A Church Undone: Documents from the German Christian Faith Movement, 1932-1940, selected, translated, and introduced by Mary M. Solberg (Minneapolis: Fortress Press 2015), 163-200, esp.: Thesis 20 of the Church of Saxony (175); the
} 
To their credit, many Lutheran churches - particularly in Germany and North America - have recognized the effects of Luther's writings and denounced them. On the occasion of Luther's $500^{\text {th }}$ birthday in 1983, building on a succession of Lutheran-Jewish dialogues both internationally and in many regional churches, the Lutheran World Federation issued a call to its member churches to delve more deeply into the issues. ${ }^{6}$ That $500^{\text {th }}$ anniversary provided ample opportunity for a closer examination and assessment also by many scholars. In the resulting give and take, debates about what seemed for a long time to be a shift in attitude from the "early Luther" to the "later Luther" have swirled around historical, theological, psychological, and rhetorical factors. Important distinctions have been drawn between his attitude toward Jews and his attitude towards Judaism, showing a greater continuity throughout his career in his antipathy to Jewish belief and practice. ${ }^{7}$ Beyond the scholarly debates, however, the churches have recognized an undeniable moral obligation to renounce the defamation and abuse that Luther heaped on the Jewish people and their religion.

\section{Lutheran and Christian Remediations}

The Evangelical Lutheran Church in America - my own church home - in 1993 voted to address the issue and in 1994 it issued its Declaration to the Jewish Community. ${ }^{8}$ The Declaration has taken its place among a wide range of Christian statements addressing not only Luther's vitriol but also the longer history of Christian anti-Jewish hermeneutics and theology. Substantial and valuable collections of these statements have been published in both English and German. ${ }^{9}$ They

exposition of "The German Prophet" by Anna Ilgenstein-Ratterfeld, who casts Hitler as the antitype of Luther (179-198, esp. 196-198); and, “Godesburg Declaration,” §3a (445-446). See also Susannah Heschel, The Aryan Jesus: Christian Theologians and the Bible in Nazi Germany (Princeton: Princeton University Press, 2008), esp. 81, 173-174; and Doris Bergen, "Storm Troopers of Christ," in Betrayal: German Churches and the Holocaust, ed. Robert P. Ericksen and Susannah Heschel (Minneapolis: Fortress Press, 1999) 47.

6 "In Christ Hope for the World," Proceedings of the Seventh Assembly, LWF Report No. 19/20 (Geneva: Lutheran World Federation, 1985), 255-256; excerpted in A Shift in Jewish-Lutheran Relations? A Lutheran contribution to Christian-Jewish dialogue with a focus on antisemitism and anti-Judaism today, LWF Documentation No. 48, ed. Wolfgang Grieve and Peter Prove (Geneva: Lutheran World Federation, 2003), 199-200.

${ }^{7}$ See Schramm, "Introduction," 9.

8 "Declaration of the Evangelical Lutheran Church in America to the Jewish Community," in Bridges: Documents of the Christian-Jewish Dialogue, Volume Two: Building a New Relationship (19862013), A Stimulus Book, ed. Franklin Sherman (Mahwah, NJ: Paulist Press, 2014), 81-82; available online in PDF format at http://elca.org/Faith/Ecumenical-and-Inter-Religious-Relations/InterReligious-Relations/Jewish-Relations.

${ }^{9}$ Franklin Sherman, Bridges: Documents of the Christian-Jewish Dialogue, Vol. 1: The Road to Reconciliation, and Vol. 2: Building a New Relationship, A Stimulus Book (Mahwah, NJ: 2011-2014); Die Kirchen und das Judentum, Band 1: Dokumente von 1945 bis 1985, ed. Rolf Rendtorff and Hans Hermann Henrix (Munich: Chr. Kaiser, 1988), Band 2: Dokumente von 1986 bis 2000, ed. Hans Hermann Henrix and Wolfgang Kraus (Paderborn/Gütersloh: Bonifatius, 2001), and Band 3: Dokumente von 2000 bis heute, ed. Hans Hermann Henrix and Reinhold Boschki (online publication at https://www.nostra-aetate.uni-bonn.de/kirchliche-dokumente/online-publikation-die-kirchen-und- 
present a common set of reflections that are now widely recognized and noncontroversial. I frame them in five "Rs" (with due recognition to Mary Boys, who published her 6 Rs simultaneously with my first work on these, though we never consulted one another about them. ${ }^{10}$ I am sure that many who teach these matters have developed similar frameworks):

Repent of the harm done to Jews by the church and Christian rulers and societies over centuries

Repudiate the teaching of contempt and adversus Judaeos hermeneutics that have characterized Christian theology and catechesis

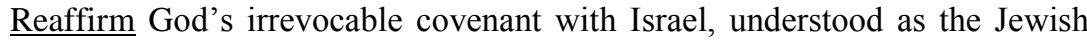
people

Rediscover the Jewish roots of Christianity, including the Jewish characters of Jesus and Paul

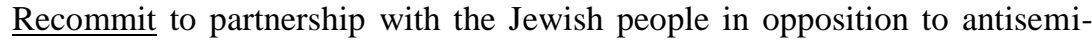
tism and in common work for justice and peace, for a righteous society, for what has come to be referenced in many Jewish-Christian dialogues as " $t i k$ kun olam"

The work of remediation in regard to Luther's controversial theology and combative style has also occupied Lutherans in recent decades in relation to the Roman Catholic community. One element of that process of dialogue and theological rapprochement offers a meaningful contribution to Lutheran-Jewish relations.

In 1999 the Vatican's Council for Promoting Christian Unity and the Lutheran World Federation signed a Joint Declaration on the Doctrine of Justification (JDDJ). ${ }^{11}$ In Luther's writings, the opponents of the gospel were frequently an undifferentiated agglomeration of "Jews, Turks, heretics, and papists," 12 all of whom he saw as claiming righteousness based on works and thus implying that "Christ died in vain" (Gal 2:21). This violated his doctrine of justification, which is the "first and chief article" of faith, the "ruler and judge of all other Christian doctrines" in Luther's theology and the Reformation (JDDJ 1). Roman Catholics,

das-judentum). See also the online research collection of statements and documents at Dialogika (http://www.ccir.us/dialogika-resources/documents-and-statements).

${ }^{10}$ Mary C. Boys, Has God Only One Blessing, A Stimulus Book (Mahwah, NJ: Paulist Press, 2000), 248.

${ }^{11}$ The Lutheran World Federation and the Roman Catholic Church, Joint Declaration on the Doctrine of Justification, English-Language Edition (Grand Rapids, MI: Wm. B. Eerdmans Publ. Co., 2000), available online in PDF format at http://elca.org/Faith/Ecumenical-and-Inter-ReligiousRelations/Bilateral.

${ }^{12}$ Schramm, "Introduction," 215, n. 14, relates, "The German linguist, Dietz Bering, has demonstrated that Luther's polemical vocabulary utilized against the Jews, the Pope, and the Turk is essentially identical." Schramm references Bering's "Gibt es bei Luther einen antisemitischen Wortschatz? Zur Widerlegung einer politischen Legende," Zeitschrift für Germanistische Linguistik 17 (1989): 137-61; and the critique of him by Osten-Sacken, Martin Luther, 26-27. 
as "papists," were thus branded with the "legalist" and "Pelagian" labels and portrayed as fundamentally opposed to the truth of Luther's gospel.

The Joint Declaration and the three decades of dialogue the preceded its adoption fashion a common ground for the different Lutheran and Roman Catholic emphases in the doctrine of justification. Roman Catholic emphases on human responsibility and the renewal of the justified in righteous living are affirmed by the Lutheran church alongside the Lutheran emphases on the sufficiency of God's grace and the dangers of hubris and self-justification; so, too, the Roman Catholic church affirms core Lutheran emphases alongside its own distinctive theological formulations. The respective, mutual condemnations of the Council of Trent and the Lutheran Confessions on these points are formally set aside in light of the joint declaration.

In taking this step, the Lutheran community implicitly also has addressed the theological content of Luther's opposition to Judaism, which also centered on justification. Luther was convinced that Jews relied on their own works and the performance of the Law to gain a right relationship with God. If the descendants of Luther's "papists" can be understood more generously and less polemically in their dialectical construal of grace and faithfulness, perhaps the descendants of Luther's "Jews" can also be engaged in fresh ways.

My colleague in Bonn, Andreas Pangritz, and his teacher, Friedrich-Wilhelm Marquardt, have challenged the JDDJ because it still asserts that "Christ has fulfilled the law and ... has overcome it" (\$31). This, they argue, reinforces the fundamentally anti-Jewish stance of Christian self-understanding and leaves the church in its age-old supersessionist posture. In their view, by reaching common agreement on this characterization of Christ as the solution to the "problem" of the Law, Lutherans and Roman Catholics tragically and inexcusably reinforce the church's anti-Judaism for a new ecumenical era. Pangritz writes, "Lutherans and Roman Catholics agreed in an anti-Judaic understanding of justification by faith alone without works of the law.... It seems to me that the Joint Declaration has not taken account of the new perspectives on Paul. Therefore, it is not helpful in Jewish-Christian relations." 13 While I grant that he is correct to note that the full assertion of JDDJ is that Christ "has overcome [the law] as a way to salvation" (§31), I would draw a different conclusion regarding the larger issue.

The JDDJ's sentence addresses a Christian neuralgia, not a Jewish error. Only those who think that Jews believe that the law saves will read this as antiJewish. They are mistaken in what they think, though, because Jews do not believe that the law saves (if "saving" is even a meaningful category for the Jewish community).

Jews do live by Torah, but they are not saved by it. Their sustaining relationship with God is established by God's will and power, embodied both in the choosing of Abraham and in the Exodus and expressed throughout centuries as a

\footnotetext{
${ }^{13}$ Andreas Pangritz, personal e-mail communication, June 28, 2017. Pangritz points to the quoted phrase in $\$ 31$ and notes: "in the appendix (Sources) it explains: 'According to Pauline doctrine this refers to the way of the Jewish (!) law as a path to salvation."”
} 
covenantal commitment to be Israel's God. No longer one among the many peoples of a world of Babel, they are the people descended from Abraham and Sarah, called out by God to be a blessing. No longer the people of Pharaoh as slaves in Egypt, they become Israel, the people of God, and the life of Torah is given to characterize their life as God's people. Torah thus is no more the redemptive force which makes that faithful life in Torah possible than "love one another" is the redemptive force that makes Christian life in Christ possible.

The problem, then, lies not in the text of JDDJ, but with thinking that "[the law] as a way of salvation" refers to Judaism. It is true that Luther suffered from this misunderstanding, like virtually all of his contemporaries and not a few people today - perhaps even some of the authors of JDDJ. However, in JDDJ, Lutherans have acknowledged that Luther similarly misunderstood, or at least exaggerated, the degree to which the Roman Catholic hierarchy promoted law as the way to salvation. JDDJ specifically takes a step back from - or beyond - that mischaracterization, while allowing for differences in emphasis between Lutherans and Roman Catholics. In that regard, rather than as a model for presenting Paul's understanding of the law, this statement can also be taken as a precedent for respecting another difference, here between the Jewish emphasis on Torah as the way of life and the Lutheran emphasis on the grace by which God through faith makes any people the people of God (Gal 3:6-9; Rom 3:28-4:25).

To return to the focal issue of Lutheran responses to the church's anti-Jewish heritage: the churches have indeed reflected on the past and on changed realities in the present, expressing their contrition and desire for reconciliation with the Jewish people. That is what the first five R's of the past several decades have achieved. But their backward glance and spiritual audit only achieve so much. Harold Ditmanson, the prominent American Lutheran interfaith leader who assembled "key Lutheran statements" as Stepping Stones to Further JewishLutheran Relationships, said in his introduction to that collection in 1990:

There is little gain in fixing sole or major responsibility on Luther. That oversimplifies the problem....

The difficult task of reconsidering the traditional theology of replacement must be carried forward because we have come to recognize the unstable character of a position that is limited to or aims primarily at the goal of defusing antisemitism and treating Jewish neighbors with respect and justice. ${ }^{14}$

In the spirit of Ditmanson's wise counsel, I would suggest that there remain before us three more Rs, beyond the five that have already shaped JewishChristian relations over the past half-century and more. The three additional Rs will occupy the balance of this study.

\footnotetext{
${ }^{14}$ Harold Ditmanson, Stepping Stones, 12-13.
} 


\section{Remaining Remediations: Reformulate, Recognize, and Reconcile}

The first remaining $\mathrm{R}$ is to reformulate Christian theology. Various individuals, over half a century now, have contributed elements of such reformulation. It seems to me, however, that the individual efforts have not yet coalesced into a Christian theology that fully relinquishes the adversus Judaeos hermeneutics which gave rise to the teaching of contempt. Friedrich-Wilhelm Marquardt and Paul Van Buren still stand as the pre-eminent figures in attempting to articulate such a theology most fully. ${ }^{15}$ Their work has been with us now for several decades and I wonder how many of the seminaries include them in the core curriculum - or at all?

In the American context, the significance of this omission is not restricted to arcane theological studies. The fundamental dynamic of adversus Judaeos hermeneutics is a splitting of human community and religious thought into dichotomies, so that understanding Christianity requires first that one understand how it is not Judaism. Rosemary Radford Ruether's classic article demonstrated that the splitting of prophetic speech is a key strategy of the adversus Judaeos tradition. When early church theologians actualized the words of Isaiah and Jeremiah, Amos and Hosea, and other prophets of biblical Israel, they taught that all the condemnations and judgment fall on the Jews, while all the promises and restoration come to the church. ${ }^{16}$

"They taught" - and the church learned too well; the dynamic of splitting has become a hallmark of the Western Christian theological tradition. It is foundational to its understanding of sin and violence. Whether with Jung we want to go farther and suggest that it is fundamental to the structure of the human self, I will leave to others. For the church it is enough to recognize that its structures of theology can easily endorse such a pernicious worldview. "Anathema sit" - it is condemned. How much of ecclesiastical history is littered with that comprehensive judgment?

That splitting is also now the American experience in terms of race and religion. The Black Lives Matter movement calls out systemic racism and there is a documented upsurge in religiously targeted bigotry and violence. It was in many ways the church and its supersessionist habits that taught Americans how to in-

\footnotetext{
${ }^{15}$ On Marquardt, see Von Elend und Heimsuchung der Theologie: Prolegomena zur Dogmatik (Munich: Chr. Kaiser Verlag, 1988) and Andreas Pangritz, "Friedrich-Wilhelm Marquart: A Theological-Biographical Sketch," in Theological Audacities: Selected Essays, Friedrich-Wilhelm Marquardt, ed. Andreas Pangritz and Paul S. Chung, Princeton Theological Monograph Series (Eugene, OR: Pickwick Publications, 2010), esp. the bibliography in footnote 69, p. 248.

On Van Buren, see A Theology of the Jewish-Christian Reality, 3 vols.: Part 1: Discerning the Way; Part 2: A Christian Theology of the People Israel; and Part 3: Christ in Context (San Francisco: Harper \& Row, 1980, 1983, 1988).

${ }^{16}$ Rosemary Radford Ruether, "The Adversus Judaeos Tradition in the Church Fathers: The Exegesis of Christian anti-Judaism," in Essential Papers on Judaism and Christianity in Conflict: From Late Antiquity to the Reformation, ed. Jeremy Cohen (New York: New York University Press, 1991), 174189.
} 
stall white supremacy as a structural tool of power. ${ }^{17}$ The model can work with any group. When we begin with the dichotomy between "our" righteousness and "their" unrighteousness, our selective attention begins to see only the unrighteousness in the other. With any degree of power we can then impose an imperial definition on the other as categorically unrighteous, and soon a whole segment of humanity has become alienated from what we consider human. And once "they" are less than human, or other than human....

In trying to address this, I have to make an important distinction. On the one hand, Christian faith teaches that there is no way to eradicate the sinfulness of this tendency. That is: no theology, no doctrinal purity, no new scholarship, no courageous confession will disentangle Christians entirely from sinfulness. People will continue to live with the tendency to use everything - and particularly religion to advance ourselves at the expense of others and in defiance of God. Mea culpa, mea maxima culpa. An essential part of confession, however, is a commitment to the amendment of life, an earnest effort to live differently from what previously led to sinful acts. And in that regard that there is much to be gained from the New Perspectives on Paul. ${ }^{18}$

One of the particular insights of that scholarly endeavor, also underway now for more than a half-century, is that Paul recognized the emergent Christian faith as the "new kid on the block." Unlike the circumstances in later Christendom and even now in a post-Christian era, it was not Judaism that needed to be justified or affirmed. Paul knew for certain the dignity and value of the Jews before God, that "to them belong the adoption, the glory, the covenants, the giving of the law, the worship, and the promises" (Rom 9:4 NRSV). What did need explaining was this new experience of the God of Israel working outside the community to offer covenantal life to the gentiles. "Or is God the God of Jews only?" as he asks in Romans 3:29.

Paul's career is marked throughout by his struggle to show how God's gracious will, which Jews knew in the faithfulness of Abraham and redemption from slavery in Egypt, also now extends to gentiles in the faithfulness of Christ and redemption from slavery to sin. Or, as the Evangelische Kirche in Deutschland said in its synod in November 2016: "the trust in God's promise to Israel and the confession of Jesus Christ belong together. The mystery of God's revelation encompasses both."19

Gentiles became the vast majority in the church very quickly after Paul's time and so it remains. When the church realizes that God brought gentiles into covenantal life not in a zero-sum victory over Israel but as an outworking of

\footnotetext{
${ }^{17}$ See James H. Cone, The Cross and the Lynching Tree (Maryknoll, NY: Orbis Books, 2011) and Willie James Jennings, The Christian Imagination: Theology and the Origins of Race (New Haven: Yale University Press, 2011).

${ }^{18}$ For distinctively Lutheran perspectives within the voluminous bibliography on this intellectual movement, see The New Perspective on Paul, ed. David C. Ratke (Minneapolis: Lutheran University Press, 2012).

${ }^{19}$ The Evangelical Church in Germany, “...'he keeps faith forever.' (Psalm 146:6): A Declaration concerning Jews and Christians as Witnesses of God' Faithfulness," $\S 3$, http://www.ccjr.us/dialogikaresources/documents-and-statements/protestant-churches/eur/1402-ekd-2016nov9.
} 
God's commitment to Israel, then the paradigm Christians can offer the world will change. The focus of the Christian challenge and calling will be able to shift.

No longer will the church feel compelled to defend its truth against assault by another's falsehood; it will be freed to seek the meaning of Christian truth as it relates to God's faithfulness to those who do not share that understanding of truth. It will be able to shift from honing the ability to convince others to be Christian to clarifying for the Christian community itself and for others just who Christians are and how they engage with a pluralistic world. That has implications for reformulating all of Christian theology, not as piecemeal modifications but from the core outward. $^{20}$

A second $\mathrm{R}$ that remains is the recognition that "the land" is integral to the promise to Israel and bears intrinsic meaning for the Jewish people. This is a fraught arena in the context of contemporary geopolitics and internal Christian diversity. By no means can the church simply say that God gave the land to Israel and therefore the current State of Israel is uniquely sanctioned by the divine will. Neither, though, can it say simply that present-day Israel has nothing to do with the Jews as a covenantal people of God and nothing to do with the promises of God to Israel in scripture.

To be frank about it, the Christian community over history has not exactly been expert at working out the theological meaning or righteous management of political sovereignty. The long history of pre-modern Christendom as a religiopolitical project brought very mixed outcomes. As the modern mentality emerged in autonomous nation-states, the separation of church and state that partly reflects Luther's two-kingdom theology has not improved the record very much. The oppressiveness of pre-modern imperialism and subsequent colonialism has simply given way to a rampant modern individualistic humanism in which the church has become nearly irrelevant. And now the capacity to engage seriously with the dangers of both models is smothered by the urgency of a conflict between them, as though they are the only choices.

The church needs to re-examine the biblical witness to discern a more promising path for political society. Part of that re-examination will deal with the creator of heaven and earth making promises of land and progeny and sovereignty to a particular people, Israel, but not exclusively to that people. "Are you not like the Ethiopians to me, O Israel? Did I not bring up Israel from Egypt, and the Philistines from Caphtor, and the Arameans from Kir?" asks the Lord through the prophet Amos (9:7). Again, and in this regard, "Can God be the God of Jews only? Is [God] not the God of gentiles also?" (Romans 3:29). The Bible suggests a dialectic between the particularity of Israel's experience and the divine commitment to all people and the whole of creation. Somewhere in that dialectic dwells a salutary framework of recognition that does not confer the privilege of exceptionalism; the present challenge is to articulate it judiciously.

\footnotetext{
${ }^{20}$ For an example of the usefulness of the deus absconditus tradition, see my "Christ Alone, the Hidden God and Lutheran Exclusivism,” Word \& World 11:2 (Spring 1991): 190-198.
} 
I would suggest that such a framework casts God's work with biblical Israel as a paradigm of God's will for all nations, extending the promises and privileges of God's favor to other nations without removing them from Israel. Previous efforts to apply the model of Israel more widely have typically taken the course of universalizing and spiritualizing, so that Israel's particularity loses its meaning. But there is nothing in scripture to suggest that God's favor, extended to other nations, requires the eclipse of Israel's blessings. It is the same as with redemption: the promise to gentiles need not, and indeed cannot, eclipse the covenant with Israel.

When God called Israel into nationhood it was with the expectation that the earth had a place on it for them; so too with the Philistines and the Arameans. And so with all nations - when God calls any nation into existence in history it is with the expectation that they will have a place on the planet. Thus, on the one hand, Israel retains its particularity in its paradigmatic role as the indispensable scriptural model; on the other hand, under God's creative and providential power, every nation - including now the Palestinian nation - enjoys a divine dignity that stands together with Israel's. ${ }^{21}$

Thus, my first two Rs that remain for remediating the church's anti-Jewish heritage: reformulating theology and recognizing the integral place of land in the biblical covenant.

As we approach the third remaining $\mathrm{R}$, reconciliation, it will be helpful to take one more backward glance: at the context in which Luther's vitriol was catalyzed into fuel for the "final solution to the Jewish question." The Jewish question that Nazism sought to "solve" was a nineteenth-century question, originally put to the Jewish people. It was, in fact, put directly in the form of twelve questions to the "assembly of Jewish notables" convened by Napoleon in $1806 .{ }^{22}$ Taken together, Napoleon's set of questions asked whether Jews could live as loyal citizens of the empire. The question is ironic in retrospect, since Jewish people had, for more than a thousand years, effectively lived as loyal citizens of dozens of different political entities across Europe, North Africa, and the Middle East, successfully adapting themselves to local circumstance in myriad ways.

With the rise of the modern nation-state, the old question presented itself in a fresh way. Once again, both in their explicit reply to Napoleon and in their accommodation to the polities not only of France but of every European country and the United States and virtually everywhere they lived, Jews have presented the answer in the affirmative. Indeed, it was the highly successful integration of the Jewish community into modern German society that made it both the convenient target and the incredulous victim of Nazism's genocidal condemnation. Tragic as that irony is and complicit as many Lutherans were in exploiting it, the Jewish answer to the old question nevertheless seems to be well established. In

\footnotetext{
${ }^{21}$ See my “Theologizing about Zionism," Christian Century 134:18 (August 30, 2017): 20-25.

${ }^{22}$ Baruch Mevorah, "Assembly of Jewish Notables," Encyclopaedia Judaica, ed. Michael Berenbaum and Fred Skolnik, $2^{\text {nd }}$ edition (Detroit: Macmillan Reference USA, 2007), 2: 599-602.
} 
the past half-century Lutherans, along with many others, have acknowledged that truth.

Yet there is a new "Jewish question," I would suggest. This question confronts not the Jews, but the churches first and then more generally the Western society which the churches have so deeply shaped. It is the church, in the person of Augustine, who first framed the categorical otherness of Jews in theological terms, and it is the church in concert with Christian rulers throughout the medieval period, who expanded that otherness to characterize Jews as religious, social, economic, and political aliens. In so doing, Christians have bequeathed to Western culture a broad sense of unease and discomfort with Jewish identity. This reaches beyond the specific foundational issues in Christian hermeneutics and theology to which the first two of the remaining R's, reformulating theology and recognizing the place of the land in the biblical witness, are addressed. It moves to the level of the arguably subconscious place that Jews have taken in the Western Christian worldview - a place that David Nirenberg has well documented in his expansive book on antisemitism. ${ }^{23}$

This new Jewish question is my third and final remaining R. It asks whether Christians and other members of Western liberal democracies can reconcile with the Jewish people as a normal part of their worldview and society. More particularly, can they remove the stigma of the alien that has attached to the Jewish community, allowing for the particularities of Jewish identity without fearing it as a subversive force? Can they normalize Jews in a worldview that also still leaves a distinctive Jewish identity intact, not having to erase it in a bland universalism or post-ethnic sensibility? Where are the resources, theologically and communally, that will enable engagement with Jews as real neighbors, unburdened by the rhetorical and metaphysical roles the West has required them to play for so many centuries?

This issue of reconciliation, the third remaining $\mathrm{R}$, awaits further attention. In many ways, it is a question more for therapy than theology. In the case of individual psychic and emotional ghosts, we know that analyzing and understanding where they came from is only a first step; working out the catharsis and developing new emotional patterns without their neurotic interruptions is a longer, more complicated, more embodied and holistic process. So, too, with the ghosts of Jews that have been conjured collectively over centuries. We engage the process only partially through the intellect, for it requires also the shaping of new experiences, the commitment to building real relationships, the cultivation of respect and regard, the hard work of better communications.

Luther was speaking in sacramental terms when he commended such engagement as "the mutual conversation and consolation" of the community. ${ }^{24}$ It is the experience of God's presence and the discernment of truth not in liturgical rites or discursive proclamation, but in human interaction. Luther himself had lit-

\footnotetext{
${ }^{23}$ David Nirenberg, Anti-Judaism: The Western Tradition (New York: W. W. Norton, 2014).

${ }^{24}$ Martin Luther, "Smalcald Articles," in The Book of Concord: The Confessions of the Evangelical Lutheran Church, ed. Robert Kolb and Timothy J. Wengert (Minneapolis: Fortress Press, 2000), 319.
} 
tle interaction with Jews in sixteenth-century Wittenberg; the opportunities for encounter that he did have were burdened both by his own theological conundrums and by cultural norms that had been centuries in the making. His record is not the place to turn for a shining example of what is needed now. But in the "better judgment" of his full theological project, there remain resources for Lutherans and others to use in moving forward. ${ }^{25}$

\section{Conclusion: Seeking New Horizons of the Lutheran Heritage}

The church's complicity in the Shoah shattered Christian illusions about the benign purity of long-standing theological models and opened up a self-critique precisely at the point of the church's central confessional claims. How deeply does the adversus Judaeos hermeneutic shape the formulations of central symbols like the creeds, ecclesiological claims to be the "new" or "true" Israel, affirmations of fulfillment in regard to God's promises to biblical Israel, and Christological images (to name but a few of the more obvious loci for reconsideration)? Can the central theological article of the Reformation, such as justification by grace through faith, with its corollaries of the faithfulness of God, the hiddenness of God, and the freedom of the gospel, guide Lutherans, especially, in developing a new hermeneutical pattern that will carry the church beyond supersession and separation to affirm Christian continuity with and relationship to the Jewish community?

The statelessness of Europe's Jews under Nazism and their vulnerability to the resulting dehumanization cast the State of Israel and the "landedness" of God's promise to biblical Israel and its modern Jewish progeny in a particular light. That bleak period also stands as a continuing challenge to any Christian defense of a purely supranational community as an adequate protector of human rights. What relationship shall now be discerned between land and people in the biblical and historical witness of the people Israel to their national identity? Can the Reformation emphases of sola scriptura and the sola gratia, rather than closing off others' insights, open a way to understanding a living Word and abundant grace that shape and empower different peoples with diverse and particular vocations as witnesses to God's ultimate sovereignty?

The globalized community and instantaneous communications technologies of our times afford ample opportunity to engage with Jews in their authentic, kaleidoscopic self-expression even for those who have little occasion to encounter Jews in person. How long can false, fabricated projections of Jewish identity, which have cultivated antisemitic animus and a diffuse Gentile discomfort with Jews and Judaism, stand before the complex human realities that are now availa-

\footnotetext{
${ }^{25}$ See Eric Gritsch, Martin Luther's Anti-Semitism: Against His Better Judgment (Grand Rapids, MI: Wm. B. Eerdmans Publ. Co., 2012) and the 2016 pamphlet by the Evangelical Lutheran Church in America's Consultative Panel on Lutheran-Jewish Relations, "Luther and Contemporary Interreligious Relations," available online in PDF format at http://elca.org/Resources/Ecumenical-andInter-Religious-Relations\#InterReligious.
} 
ble on our many screens? The Reformation carried a conviction that the gospel always comes to people from outside themselves and that critical reason is a partner with holy scripture in discerning truth; can these build courage in individual Christians to open their senses and their hearts to a community too long obscured by doctrinal denunciations and rejected as essentially anachronistic?

With these questions I can offer here only hints of the particular ways in which Lutheran themes and theology might open the church to new horizons in its relationship with the Jewish people and with Judaism. Other Christian communities will contribute their own resources, and the Jewish community will be a critical, indispensable interlocutor in the process. As the next 500 years of the Lutheran witness rise ahead, Lutherans can turn the tools of their theological tradition toward fashioning effective responses to the remaining challenges bequeathed by Luther and the longer church tradition he conveyed, and fashion a new Lutheran heritage of engagement with Jews and Judaism.

Endnote: Herewith the colleagues and communities whose welcome engagement contributed to this article:

My primary theological partner of the past half-dozen years at the Shalom Hartman Institute, Dr. Marcie Lenk; my co-teacher in the 2017 minicourse of the Institute for Jewish-Christian Understanding of Muhlenberg College, Ms. Jude-Laure Denis, and her posse and thought partners at POWER Northeast in Allentown PA; The Kripke Center of Creighton University and its director, Prof. Ron Simkins, as well as Prof. Leonard Greenspoon, Beth El Synagogue, and St. Michael's Lutheran Church, all of Omaha; the International Council of Christians and Jews, its president, Dr. Philip Cunningham, and the 2017 annual conference program co-chairs, Ms. Liliane Apotheker and the Rev. Barbara Rudolph, as well as my co-presenter, Prof. Andreas Pangritz; Luther Crest Community, Allentown PA, and its chaplain, the Rev. Virginia Heimer; PAIRS of the Southeastern Pennsylvania ELCA Synod and its convener, the Rev. John Kerr; the Brother John G. Driscoll Professorship of Iona College, New Rochelle NY, and its incumbent, Prof. Elena Procario-Foley, along with her partners in the Shared Roots, Divergent Paths program from the Westchester Chapter of the American Jewish Committee and my co-presenter, Dr. Malka Simkovitch; the Institute of Judaeo-Christian Studies at Seton Hall University and its director, Fr. Lawrence Frizzell; the Religion Studies department of Muhlenberg College and its chair, Prof. William Gruen; and, finally, my peer reviewers and editor at SCJR. 